\title{
Reduction of IGF-binding protein-3 as a potential marker of intra-uterine growth restriction
}

\author{
Maria Dalva Barbosa Baker Méio ${ }^{1, *}$, Maria \\ Elizabeth Lopes Moreira ${ }^{2}$, Rosely Sichieri ${ }^{3}$ \\ and Aníbal Sanchez Moura ${ }^{4}$ \\ ${ }^{1}$ Instituto Fernandes Figueira - Fundação Oswaldo \\ Cruz, Rua Nascimento Silva, 111/502 A, Ipanema - \\ Rio de Janeiro, Rio de Janeiro, CEP 22421-020 \\ 2 Instituto Fernandes Figueira - Fundação Oswaldo \\ Cruz, Rua Prudente de Moraes, 368/808, Ipanema - \\ Rio de Janeiro, Rio de Janeiro, CEP 22420-040 \\ ${ }^{3}$ Instituto de Medicina Social, Universidade do Estado \\ do Rio de Janeiro, Rua São Francisco Xavier 524, \\ 7 andar. Maracanã, Rio de Janeiro, Rio de Janeiro, \\ CEP 20550-012 \\ ${ }^{4}$ Laboratório de Fisiologia da Nutrição e do \\ Desenvolvimento, Departamento de Ciências \\ Fisiológicas, IBRAG, Universidade do Estado do Rio \\ de Janeiro, Avenida 28 de Setembro 87, fundos $5^{\circ}$ \\ andar Rio de Janeiro, Rio de Janeiro, CEP 20550-030
}

\begin{abstract}
Background: Growth factor-binding proteins influence the growth of infants starting in utero. Adaptation of the fetus to an adverse uterine environment is associated with changes in the growth hormone-growth factorinsulin axis.

Aims: To evaluate serum levels of IGF-I and IGFBP-3 in small and appropriate for gestational age newborn infants.

Methods: Fifty-four newborn infants, small (SGA, $n=28$ ) or appropriate (AGA, $n=26$ ) for gestational age were matched by gestational age and sex. Blood was collected on the first day of life, and anthropometric measurements were taken at birth. The serum levels of IGF-I and IGFBP-3 were compared, and correlated with the anthropometric measurements.

Results: On the first day of life, mean serum IGFBP-3 levels were significantly lower in SGA babies and correlated with weight, length, head circumference, and ponderal index (weight/length 3$)(P<0.0001)$. In contrast, no
\end{abstract}

\footnotetext{
${ }^{*}$ Corresponding author:

Maria Dalva Barbosa Baker Méio

Instituto Fernandes Figueira

Department of Neonatology

Avenida Rui Barbosa 717

Flamengo

Rio de Janeiro

Brazil

E-mail: mdmeio@centroin.com.br; dalvameio@iff.fiocruz.br
}

associations were found between IGF-I serum levels and these anthropometric measurements.

Conclusion: Our data show that SGA babies have significantly reduced IGFBP-3 concentrations at birth.

Keywords: IGF-binding protein-3; insulin-like growth factor-I; small for gestational age.

\section{Introduction}

Insulin growth factors have a central role in fetalplacental growth throughout gestation. It has been shown that insulin-like growth factor (IGF)-I levels at birth are lower in small for gestational age (SGA) than in appropriate for gestational age (AGA) preterm newborns [10, 20], although other studies evaluating only term SGA newborns found higher IGF-I levels [29, 32] than in AGA infants. Changes in the hormonal milieu may be a consequence of the adaptation of the fetus during intrauterine life to a hostile environment of maternal, placental or fetal origin in order to improve survival. Many studies have shown that this adaptation has consequences either in the neonatal period or later [8, 14, 26]; for example, there is the high risk of developing insulin resistance at the end of childhood or as young adults for SGA and premature children $[6,11,12,21,33]$. The endocrine reprogramming that occurs in this population is the result of modifications in the growth hormone-growth factorinsulin axis during intra-uterine life and is influenced by nutrition in the first post-natal weeks [1, 28].

In addition, circulating IGF-1 forms complexes with binding proteins (IGFBPs), whose physiological functions include transport, reservoir, protection from proteolytic degradation, and the ability to activate receptors on target cells [27]. Therefore, serum IGFBPs, especially IGFBP-3 [15, 30], are important markers of growth.

In this study, we evaluated the serum levels of IGF-I and IGFBP-3 in SGA and AGA newborn infants at birth, matched by gestational age and sex, to test the hypothesis that intrauterine growth restriction is associated with these hormones early in life.

\section{Methods}

All SGA newborn infants born between 1 July 2005 and 31 June 2006 at the Instituto Fernandes Figueira maternity, Rio de Janeiro, Brazil, were included in the study. SGA newborn infants were matched with AGA newborn infants, born in the 
same period and unit, by gestational age and sex. The exclusion criteria were congenital malformations, congenital infections and genetic syndromes.

SGA was defined as birth weight $\leq 2 \mathrm{SD}$ (standard deviation) below the mean (weight for age Z-score, $\leq-2 \mathrm{SD}$ ) using the Kramer's reference data [16], a restricted definition by the international consensus published by Lee et al. [19]. The children with birth weights above the cut-off were considered AGA. Gestational age was calculated from the last menstrual period (40), early ultrasound (9), or the New Ballard score (5), in that order of preference.

Anthropometric measurements were taken at birth by trained nurses. Weight was measured with a digital scale (precision of $5 \mathrm{~g}$ ). An appropriate scale for an incubator was used for length measurements and an inextensible tape was used for head circumference measurements. Blood samples were taken on the first day of life.

Serum IGF-I and IGFBP-3 levels were measured in the Laboratório de Fisiologia da Nutrição e do Desenvolvimento, Departamento de Ciências Fisiológicas, IBRAG, Universidade do Estado do Rio de Janeiro, by radioimmuno assay (IRMA ${ }^{\mathrm{TM}}$ Active IGFBP-3 DSL-6600 and IRMA ${ }^{\text {TM }}$ Active IGF-1 DSL-5600). The IGF-I extraction was done with an $\mathrm{HCl}$ ethanol solution. An antiIGF-I antibody marked with I-125 was used for IGF-I measurements. The coefficients of variation were 3.0 for intra-assay (mean $=52.5 \mathrm{ng} / \mathrm{mL} ; \mathrm{SD}=16.4$ ) and 1.5 for the inter-assay (mean $=53.8 \mathrm{ng} / \mathrm{mL} ; \mathrm{SD}=8.0$ ) differences. An anti-IGFBP-3 polyclonal goat antibody marked with $\mathrm{l}-125$ was used for IGFBP-3 measurements. The coefficients of variation were 3.2 for the intra-assay (mean $=27.23 \mathrm{ng} / \mathrm{mL} ; \mathrm{SD}=1.4$ ) and 1.5 for the inter-assay (mean $=21.9 \mathrm{ng} / \mathrm{mL} ; \mathrm{SD}=0.1$ ) differences.

Differences in proportions were evaluated using the $\chi^{2}$-test with Yates correction. A non-parametric test (Wilcoxon test) was used for comparisons of the levels of IGF-I and IGFBP-3 between the groups, and a Spearman correlation was used to analyze the relationship between these factors and birth weight, head circumference, length at birth and ponderal index. All analyses used the SAS (Statistic Analysis System, version 9.01) software. The study was approved by the Ethics Committee of the Institution, and one of the parents signed a written informed consent.

\section{Results}

The mothers of 57 children were invited to participate, and $54(94.7 \%)$ agreed. Due to paired inclusion, 28 were SGA (17 preterm) and 26 were AGA (15 preterm). The demographic characteristics of the population are shown in Table 1. There were no significant differences between the two groups at birth, except for birth weight, birth length, head circumference and weight for age Z-score $(P<0.0001)$.

On the first day of life, mean serum levels of IGFBP-3 but not of IGF-I were significantly lower in SGA babies (Table 2). There were borderline correlations between IGF-I and birth weight $(0.28, P=0.048)$ and IGF-I and the ponderal index $(0.27, P=0.06)$. However, there were no correlations between IGF-I and length at birth, head circumference at birth or gestational age ( $P$-values of 0.12 , 0.41 and 0.22 , respectively). IGFBP-3 had a strong, positive correlation with birth weight $(0.67, \mathrm{P}<0.0001)$, birth length (0.64, $P<0.0001)$, head circumference $(0.60$, $\mathrm{P}<0.0001)$, ponderal index $(0.69, \mathrm{P}<0.0001)$ and gestational age $(0.44, \mathrm{P}=0.001)$.

\section{Discussion}

In this study, no significant difference was found in the IGF-I levels between SGA and AGA newborn infants on the first day of life, although IGFBP-3 levels were lower in SGA infants. This lack of difference between SGA and

Table 1 Characteristics at birth of the small for gestational age (SGA) and appropriate for gestational age (AGA) newborn infants.

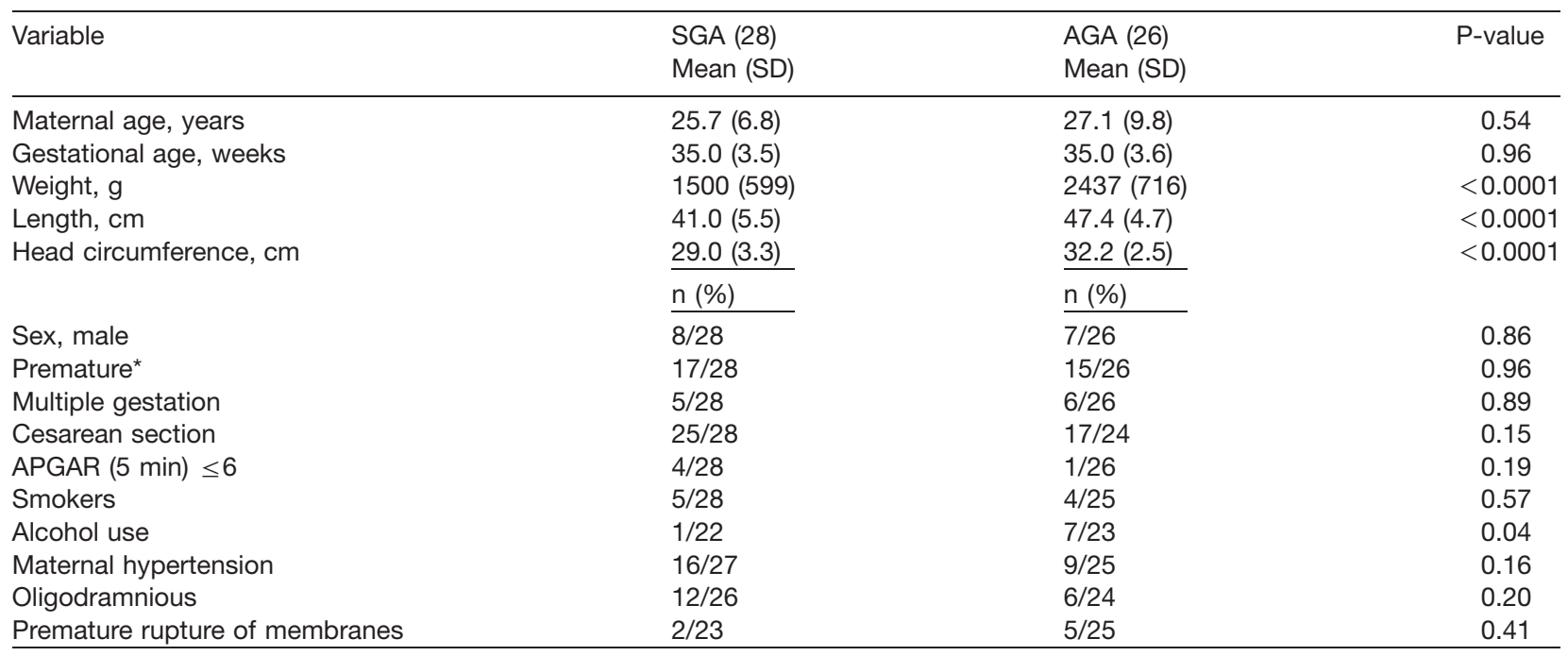

${ }^{*} 14 / 54(25.6 \%)$ gestational age $<33$ weeks.

$\mathrm{SD}=$ standard deviation, $\mathrm{SGA}=$ small for gestational age, $\mathrm{AGA}=$ appropriate for gestational age . 
Table 2 Means, SD and 95\% Cl of IGF-I and IGFBP-3 serum levels for SGA and AGA newborn infants in the first day of life.

\begin{tabular}{llll}
\hline Variable & SGA (26) & AGA (25) & P-value \\
& Mean (SD) 95\% Cl & Mean (SD) 95\% Cl & 0.17 \\
\hline IGF-I (ng/dL) & $2.78(2.37) 1.82-3.74$ & $3.99(3.04) 2.73-5.24$ & 0.007 \\
\hline IGFBP-3 (ng/dL) & $541.9(295.9) 455.4-628.5$ & $682.4(287.1) 597.2-767.6$ & \\
\hline
\end{tabular}

Wilcoxon test.

$\mathrm{SD}=$ standard deviation, $\mathrm{Cl}=$ confidence interval, $\mathrm{SGA}=$ small for gestational age, $\mathrm{AGA}=$ appropriate for gestational age .

matched controls indicates the important role of gestational age in IGF-I changes. This observation is in agreement with a previous study performed with fetal blood samples that showed a progressive increase in IGFI levels with gestational age; by comparing the IGF-I levels of small (below the mean weight for gestational age) and large (above the mean weight for gestational age) fetuses, the authors found lower levels in the small fetus, although the difference between the groups was not significant up to 33 weeks of gestation [18]. The infants included in the present study are a heterogeneous population in relation to gestational age, as they were selected as SGA independent of gestational age, as were their counterparts: about $60 \%$ in each group were preterm, and $25.9 \%$ of the entire population had a gestational age of $<33$ weeks.

Levels of IGF-1 for gestational age reported in fetal samples throughout gestation have shown an increase toward the end of gestation $[9,17,18]$. There are also reports of IGF-I levels in cord blood [2, 22, 25, 30, 32] and a decrease in IGF-I levels from cord blood to the first and fourth days of life has been observed [10, 23, 29]. However, Giudice et al. (1995) obtained different results, showing that IGF-I levels were unchanged in preterm newborn infants, whereas in term neonates IGF-I levels decreased on day one, remained low during the first three days of life, and then increased to birth levels by the end of the first week [10]. In our study, blood was collected on the first day of life from babies of different gestational ages due to the matching by gestational age and sex. Consequently, our IGF-I and IGFBP-3 values are not comparable to those reported in the literature because they represent mean values from preterm and full-term neonates.

On the other hand, the lack of difference in IGF-I levels between SGA and AGA infants on the first day of life could be the effect of attenuation since approximately one fourth of the babies had a gestational age of $<33$ weeks, where a difference in IGF-I levels between SGA and AGA infants would not be expected. IGFBP-3 levels have no correlation with gestational age [18] and, therefore, were not influenced by the prevalence of preterm babies in this sample born at $<33$ weeks. Only two previous reports of higher IGF-I levels in SGA newborn infants $[29,32]$ and one report of a lack of difference in IGF-I levels between AGA and SGA newborn infants [25] were found.
In a study considering constitutional growth potential based on maternal characteristics, Mamelle et al. (2006) demonstrated that the group of infants classically classified as SGA was heterogeneous in respect to having suffered in utero growth restriction: some were SGA by weight and/or length but were in fact not growth restricted [24]. Additionally, some infants, classified as AGA by weight and/or length, had suffered growth restriction [24]. This could also happen in our population, confounding the results of IGF-I on the first day of life. Verkauskiene et al. (2007) showed that cord IGF-I and IGFBP-3 concentrations were significantly decreased in growth-restricted infants, defined by serial ultrasound measurements during gestation, in both AGA and SGA babies [31]. Their study used two classifications to define growth restriction: 1) a reduction of $>20 \%$ of the estimated fetal weight from the $22^{\text {nd }}$ gestational week until birth, based on serial ultrasound scans, and 2) a classification at birth as AGA or SGA using the $10^{\text {th }}$ percentile of a customized growth chart as a cut-off. Similar to Mamelle et al. (2006) [24], Verkauskiene et al. (2007) found AGA babies who were growth restricted and SGA babies who were not growth restricted. In our study, we tried to minimize this difficulty by using a more restricted cut-off to define SGA: birth weight equal to or $<2$ SD below the mean. In conclusion, the correct classification of growth restriction in utero is extremely important for understanding its effect on the hormonal status of the newborn infant.

Although this study did not reveal differences in the levels of IGF-I between the two groups of infants in the first day of life, IGFBP-3 levels were lower in SGA babies and strongly correlated with weight, length, head circumference and ponderal index, demonstrating its role in fetal growth here and in other studies $[7,13]$. The apparent disassociation between IGF-I and IGFBP-3 levels in this particular situation may be explained by the actions of IGFBP-3 [3, 4]. IGFBP-3 is the most abundant IGFBP circulating in human serum, has both inhibitory and stimulatory effects in cell systems, and modulates growth. IGFBP-3 can prevent IGF-I from binding to its receptors since IGF-I has a higher affinity to IGFBP-3 than to the IGF-I receptor, thus having an inhibitory action on growth. IGFBP-3 also functions as a reservoir of IGF-I, carrying it to target cells [4]. In addition, IGFBP-3 not only carries IGF-I to the target organs, but also activates IGF-I receptors on target cells. However, IGFBP-3 alone 
has no direct stimulatory effect; it acts through activation of IGF-I receptors. It has been demonstrated that IGFBP3 increases the bioeffectiveness of IGF-I by 2- to 4-fold [5]. Therefore, the equal levels of IGF-I in both AGA and SGA babies and lower levels of IGFBP-3 in SGA babies may indicate that action of IGF-I is diminished by IGFBP3 reduction, resulting in the growth restriction of children.

In conclusion, this study demonstrates that IGFBP-3 plays an important role in promoting fetal growth and is a good marker for evaluating in utero growth. However, the classification of in utero growth restriction is fundamental to documenting this evidence. It is important to identify these children at birth because they could be at risk for metabolic diseases later in life.

\section{References}

[1] Albertsson-Wikland K, Boguszewski M, Karlberg J. Children born small-for-gestational age: postnatal growth and hormonal status. Horm Res. 1998;49(Suppl 2):7-13.

[2] Barrios V, Argente J, Pozo J, Hervás F, Muñoz MT, Sánchez Jl, et al. Insulin-like growth factor I, insulin-like growth factor binding proteins, and growth hormone binding protein is Spanish premature and full-term newborns. Horm Res. 1996;46:130-7.

[3] Baxter RC. Insulin-like growth factor (IGF)-binding proteins: interactions with IGFs and intrinsic bioactivities. Am J Physiol Endocrinol Metab. 2000;278:E967-76.

[4] Collett-Solberg PF, Cohen P. Genetics, chemistry, and function of the IGF/IGFBP system. Endocrine. 2000;12: 121-36.

[5] Conover CA, Bale LK, Durham SK, Powell DR. Insulin-like growth factor (IGF) binding protein-3 potentiation of IGF action is mediated through the phosphatidylinositol-3kinase pathway and is associated with alteration in protein kinase B/AKT sensitivity. Endocrinology. 2000;141:3098103.

[6] Cutfield WS, Regan FA, Jackson WE, Jefferies CA, Robinson EM, Harris M, et al. The endocrine consequences for very low birth weight premature infants. Growth Horm IGF Res. 2004;14:S130-5.

[7] Geary MPP, Pringle PJ, Rodeck CH, Kingdom JCP, Hindmarsh PC. Sexual dimorphism in the growth hormone and insulin-like growth factor axis at birth. J Clin Endocrinol Metab. 2003;88:3708-14.

[8] Gluckman PD, Cutfield W, Harding JE, Milner D, Jensen $E$, Woodhall S, et al. Metabolic consequences of intrauterine growth retardation. Acta Paediatr Suppl. 1996; 417:3-6.

[9] Gohlke BC, Fahnenstich H, Dame C, Albers N. Longitudinal data for intrauterine levels of fetal IGF-I and IGF-II. Horm Res. 2004;61:200-4.

[10] Guidice LC, de Zegher F, Garbosky SE, et al. Insulin-like growth factors and their binding proteins in the term and preterm human fetus and neonate with normal and extremes of intrauterine growth. J Clin Endocrinol Metab. 1995;80:1548-55.

[11] Hofman PL, Cutfield WS, Robinson EM, Bergman RN, Menon RK, Sperling MA, et al. Insulin resistance in short children with intrauterine growth retardation. J Clin Endocrinol Metab. 1997;82:402-6.
[12] Hofman PL, Regan F, Harris M, Robinson E, Jackson W, Cutfield WS. The metabolic consequences of prematurity. Growth Horm IGF Res. 2004;14:S136-9.

[13] Hui-Chen L, Tsao L-Y, Hsu W-Y, Chen H-N, Yu W-K, Chi C-Y. Relation of cord serum levels of growth hormone, insulin-like growth factors, insulin-like growth factor binding proteins, leptin, and interleukin- 6 with birth weight, birth length, and head circumference in term and preterm neonates. Nutrition. 2002;18:604-8.

[14] Ibáñez L, Ong K, Dunger DB, de Zegher F. Early development of adiposity and insulin resistance after catch-up weight gain in small-for-gestational-age children. J Clin Endocrinol Metab. 2006;91:2153-8.

[15] Juul A. Serum levels of insulin-like growth factor I and its binding proteins in health and disease. Growth Horm IGF Res. 2003;13:113-70.

[16] Kramer MS, Platt RW, Wen SW, Joseph KS, Allen A, Abrahamowics $M$, et al. A new and improved population-based Canadian reference for birth weight for gestational age. Pediatrics. 2001;108:e35. http://www.pediatrics.org/cgi/ content/full/108/2/e35.

[17] Langford K, Nicolaides K, Mielli JP. Maternal and fetal insulin-like growth factors and their binding proteins in the second and third trimesters of human pregnancy. Human Reproduction. 1998;13:1389-93.

[18] Lassarre C, Hardouin S, Daffos F, Forestier F, Frankenne F, Binoux M. Serum insulin-like growth factors and insulinlike growth factor binding proteins in the human fetus. Relationship with growth in normal subjects and in subjects with intrauterine growth retardation. Pediatr Res. 1991;29:219-25.

[19] Lee PA, Chernausek SD, Hokken-Koelega ACS, Czernichow P. International small for gestational age advisory board consensus development conference statement: management of short children born small for gestational age, April 24-October 1, 2001. Pediatrics. 2003;111:125361.

[20] Leger J, Noel M, Limal JM, Czernichow P. Growth factors and intrauterine growth retardation. II. Serum growth hormone, insulin-like growth factor (IGF) I, and IGF-binding protein 3 levels in children with intrauterine retardation compared with normal control subjects: prospective study from birth to two years of age. Pediatr Res. 1996;40:1017.

[21] Leger J, Levy-Marchal C, Bloch J, Pinet A, Chevenne D, Porquet $\mathrm{D}$, et al. Reduced final height and indications for insulin resistance in 20 years old born small for gestational age: regional cohort study. Br Med J. 1997;315:341-7.

[22] Lo H-C, Tsao L-Y, Hsu W-Y, Chen H-N, Yu W-K, Chi C-Y. Relation of cord serum levels of growth hormone, insulinlike growth factors, insulin-like growth factor binding proteins, leptin, and interleukine- 6 with birth weight, birth length, and head circumference in term and preterm neonates. Nutrition. 2002;18:604-8.

[23] Malamitsi-Puchner A, Briana DD, Gourgiotis D, Boutsikou M, Puchner K-P, Baka S, et al. Insulin-like growth factor (IGF)-I and insulin in normal and growth-restricted mother/ infant pairs. Mediators Inflamm. 2007;2007:42646.

[24] Mamelle N, Boniol M, Rivière O, Joly MO, Mellier G, Maria $B$, et al. Identification of newborns with fetal growth restriction (FGR) in weight and/or length based on constitutional growth potential. Eur J Pediatr. 2006;165:717-25.

[25] Martínez-Cordero C, Amador-Licona A, Guízar-Mendoza JM, Hernández-Méndez J, Ruelas-Orozco G. Body fat at birth and cord blood levels of insulin, adiponectin, leptin, 
and insulin growth factor-I in small-for-gestational-age infants. Arch Med Res. 2006;37:490-4.

[26] Modi N, Thomas EL, Harrington TAM, Uthaya S, Doré CJ, Bell DJ. Determinants of adiposity during pre-weaning postnatal growth in appropriately grown and growthrestricted term infants. Pediatr Res. 2006;60:345-8.

[27] Mohan S, Baylink DJ. IGF-binding proteins are multifunctional and act via IGF-dependent and -independent mechanisms. J Endocrinol. 2002;175:19-31.

[28] Singhal A, Fewtrell M, Cole TJ, Lucas A. Low nutrient intake and early growth for later insulin resistance in adolescents born preterm. Lancet. 2003;361:1089-97.

[29] Varvarigou A, Vagenakis AG, Makri M, Beratis NG. Growth hormone, insulin-like growth factor-I and prolactin in small for gestational age neonates. Biology Neonate. 1994;65: 94-102.

[30] Verhaeghe J, Van Bree R, Van Herck E, Laureys J, Bouillon $\mathrm{R}$, Van Assche A. C-peptide, insulin-like growth factors I and II, and insulin-like growth factor binding protein-1 in umbilical cord serum: correlations with birth weight. Am J Obstet Gynecol. 1993;169:89-97.
[31] Verkauskiene R, Beltrand J, Claris O, Chevenne D, Deghmoun S, Dorgeret $\mathrm{S}$, et al. Impact of fetal growth restriction on body composition and hormonal status at birth in infants of small and appropriate weight for gestational age. Eur J Endocrinol. 2007;157:605-12.

[32] Wang HS, Lim J, English J, Irvine L, Chard T. The concentration of insulin-like growth factor-I and insulin-like growth factor-binding protein-1 in human umbilical cord serum at delivery: relation to fetal weight. J Endocrinol. 1991;129: 459-64.

[33] Woods KA, van Helvoirt M, Ong KKL, Mohn A, Levy J, De Zegher $\mathrm{F}$, et al. The somatotropic axis in short children born small for gestational age: relation to insulin resistance. Pediatr Res. 2002;51:76-80.

The authors stated that there are no conflicts of interest regarding the publication of this article.

Received February 25, 2009. Revised May 12, 2009. Accepted June 11, 2009. Previously published online July 10, 2009. 